\title{
Exploring positioning as an analytical tool for understanding becoming mathematics teachers' identities
}

\author{
Kicki Skog • Annica Andersson
}

Received: 30 September 2013 / Revised: 7 April 2014 / Accepted: 16 April 2014

(C) Mathematics Education Research Group of Australasia, Inc. 2014

\begin{abstract}
The aim of this article is to explore how a sociopolitical analysis can contribute to a deeper understanding of critical aspects for becoming primary mathematics teachers' identities during teacher education. The question we ask is the following: How may power relations in university settings affect becoming mathematics teachers' subject positioning? We elaborate on the elusive and interrelated concepts of identity, positioning and power, seen as dynamic and changeable. As these concepts represent three interconnected parts of research analysis in an on-going larger project data from different sources will be used in this illustration. In this paper, we clarify the theoretical stance, ground the concepts historically and strive to connect them to research analysis. In this way, we show that power relations and subject positioning in social settings are critical aspects and need to be taken seriously into account if we aim at understanding becoming teachers' identities.
\end{abstract}

Keywords Positioning $\cdot$ Discourse $\cdot$ Power $\cdot$ Identity $\cdot$ Mathematics $\cdot$ Becoming teachers

\section{Introduction}

In this article, we explore how an analysis of becoming mathematics teachers' subject positionings can reveal power relations in discursive practices in university contexts. By taking a stance within the sociopolitical theoretical perspective, we strive for opening up well-known contexts for scrutiny and analysis; an approach which is rare within the Swedish teacher education field. Research focusing on becoming mathematics teachers at Swedish universities is mainly conducted within two strands: on specific mathematical topics and on the transition from student to teacher. Studies on specific mathematical topics indicate for instance that becoming teachers have

K. Skog $(\bowtie) \cdot$ A. Andersson

Department of Mathematics and Science Education, Stockholm University, 10691 Stockholm, Sweden e-mail: Kicki.Skog@mnd.su.se

\footnotetext{
A. Andersson

e-mail: Annica.Andersson@mnd.su.se
} 
difficulties in using correct mathematical vocabulary in lower secondary school (Nilsson 2005) and strive for understanding students' perceptions regarding teaching and learning of functions (Hansson 2006).

The transition from being a student at a university to become a mathematics teacher in school often focus on institutional and social perspectives in the process of becoming a mathematics teacher. Bjerneby-Häll (2006) showed that becoming mathematics teachers' arguments for teaching mathematics changed during the first years as teachers and came to be identical with the goals of the national syllabus. The teachers in Persson's (2009) study were concerned about not having enough mathematical and didactical competence as novice teachers, even though they felt well prepared for mathematics teaching in preschool and primary school. Palmér (2013) took a critical stance and analysed novice teachers' identity development during the first years as employed. She found that they, who did not get employed as teachers after graduation, developed a vulnerable identity as mathematics teachers. Palmér argues that to become a mathematics teacher it is not enough to fullfill individual criteria such as graduation and knowledge. Without employment in a school, and without being responsible for planning and teaching an own class, including having colleagues, there were no visible processes of mathematics teacher identity development in her data. These studies bring forward issues about attitudes and experiences with regard to mathematics teaching. They also shed light on institutional constraints in schools that push back what the student teachers have learnt in teacher education and foreground issues that may arise during novice teachers' first working year(s) when becoming members in the mathematics teacher community. Supported by feminist poststructural theories Palmer (2010) investigated becoming teachers' subjectification processes in relation to the subject of mathematics. She showed how student teachers constituted mathematical subjectivity through complex networks of social relations, discourses, gender, material practices, time and space.

Even though the latter studies on identity and subjectivity clearly strives for understanding what it means to be or become a mathematics teacher or, as in Palmer (2010), to become mathematical, there is still lack of research that strives for understanding why students talk and act the way they do in relation to being part of mathematics teacher education in Sweden.

A sociopolitical theoretical perspective opens up for scrutiny of power at play (Valero 2004) and involves taking into account issues of equity and social justice. Atweh (2009) states that "issues relating to gender, multiculturalism, ethnomathematics, and the effects of ethnicity, indigeneity, socio-economic and cultural backgrounds of students on their participation and performance in mathematics are regularly discussed in the literature" (p. 112). This approach is claimed by several researchers to be not so common within mathematics education research (cf. Adler and Davies 2006; Gutiérrez 2013). However, in the years between 2007 and 2009, several special issues focusing equity and social justice have been published in mathematics education journals, and Sánchez (2011) identifies social justice as one of the new trends in mathematics teacher education research.

The need for sociopolitical approaches in mathematics education research is also acknowledged by Sriraman and English (2010), who refer to the rapidly growing field of mathematics education research the last three decades has been "heavily influenced by the social, cultural and political dimensions of education, thinking and learning" ( $p$. 
25). The relevance for this impact is discussed by the authors, who point at some issues, closely connected to mathematics education, which would be impossible to research without taking into consideration the social, cultural and political aspects. However, they do not suggest any questions specifically related to teacher education or professional development. They exemplify by posing questions focusing why school mathematics repeatedly fail minorities, why is mathematics is viewed as an insignificant school subject by some disadvantaged youths or why is mathematics education the target of so much political/policy attention? (Sriraman and English 2010)

International research on equity and social justice within mathematics teacher education has hitherto mainly put emphasis on developing and evaluating courses where the students are expected to learn about social justice, for instance as de Freitas and Zolkower (2009), by drawing attention to and facilitate for student teachers' deconstruction of discursive norms of school mathematics. Adler and Davies (2006) highlight power asymmetries between courses in mathematics and mathematics education. Issues that they argue are important in order to grasp sociopolitical concerns on a structural and institutional level. This in turn can increase awareness of mathematics as a subject which is important from several perspectives, such as social, cultural, economical, etc. However, even from an international perspective, there is a lack of research that aims at giving voice to becoming mathematics teachers, and also to put light on how social and political factors affect their experiences as becoming teachers. In order to approach this, we argue that there is a need to draw on theories that allows the analysis to reveal underlying factors that impact student's talk about their situation.

Therefore, in this article, we show how positioning, power and identity can be helpful concepts for analysing and hence promote understanding of the dynamics within discourses in a teacher education programme. Discourse is understood as "all forms of spoken interaction, formal and informal, and written texts of all kinds" in line with Potter and Wetherell (1987, p. 7). The overall research question we ask concerns relationships between power relations in university settings and becoming mathematics teachers' discursive subject positionings. We ask this question because we want to explore possibilities, challenges and constraints that student teachers experience; hence, what they talk about and how they act with regard to these experiences. These issues imply a move beyond sociocultural theories with a focus on culture and participation structures and, in Gutiérrez (2013) words, also "privilege the voices of subordinated groups and forefront the politics and power dynamics that arise from sites of interaction" (p. 39). By drawing on empirical work undertaken in a larger longitudinal study, we illustrate how positioning and power are simultaneously working and thus become possible analytical tools for understanding the complexity of becoming teachers' identity construction.

\section{Implications of taking a sociopolitical approach}

Mathematics education research has undergone what Lerman (2000) calls "the social turn", which he defines as "the emergence into the mathematics education research community of theories that see meaning, thinking and reasoning as products of social activity" (p. 23). This turn made researchers in the field rethink learning as a social activity and the situated theories of Lave and Wenger became powerful for understanding learning as becoming through participation in practice (Wenger 1998); for instance, 
how becoming mathematics teachers become practicing teachers through participation in relevant practices of mathematics teaching (Palmér 2013). From the sociocultural theoretical perspective, it is possible to understand how social practices set the rules for how we act and what we do in a practice. In this research, we adhere to Andersson's (2011b) understanding that "(mathematics) classrooms are spaces of socially organized practices that, in different ways, shape how individuals are expected to, allowed to and/ or required to act" (p. 215).

However, the social and cultural theoretical approaches do not necessarily address political issues in mathematics education (Gutiérrez 2013; Valero 2004). The sociopolitical turn in mathematics education research offers an additional layer that highlights issues of power at play in interactions, thereby helping us better reflect on and contribute to the complexity in our society (Gutiérrez 2013). This approach hence supports us to rethink learning as a political and social activity (Valero 2004; Gutiérrez 2013), which provides an additional dimension to learning through participation in communities of practice (Wenger 1998). The sociopolitical theoretical approach stresses the importance of transparency to make the familiar seem strange and to make takenfor-granted roles more explicit; of subjectivity to see the individual as constantly in the making, defying categories; and agency/voice to understand individuals negotiating and sometimes showing resistance to the discourse (Gutiérrez 2013). By taking a sociopolitical theoretical perspective we go behind the scenes of well-known contexts and as researchers "engage in a more uncertain process of knowledge construction and sense making about the practices of mathematics education" (Valero 2009, p. 241). In the next section, we place positioning, power and identity within the sociopolitical theoretical perspective to illustrate how we see the three elusive concepts working together in the present study.

\section{Positioning, power and identity}

\section{Positioning}

Positioning is a conversational phenomenon through which the actors are positioned by themselves or by others (cf. Davies and Harré 1999; Holland et al. 1998; Setati 2008). In contemporary, sociopolitical research positioning is central and used as indicator of how power relations determine discourses and how individuals take up different positionings as a consequence of these discourses (Davies and Harré 1999). Positioning is dynamic, which implies that one single person will enact different storylines in parallel, depending on whether the situation is well known or rare, if the person is experienced or a newcomer. Posed in other words: what a person tells or does to position him- or herself will differ and change, depending on the situation (Davies and Harré 1999) or context (Andersson 2011a, b). This could happen almost simultaneously. Positioning could also be strategic, meaning that people will tell different stories about themselves depending on how they want to be presented:

[T] he catalogue of kinds of positions that exist here and now will not necessarily be found at other places and times. In so far as the content of a position is defined in terms of rights, duties and obligations of speaking with respect to the social 
forces of what can be said, and these 'moral' properties are locally and momentarily specified, positions will be unstable in content as well. (van Langenhove \& Harré , 1999, p. 29)

The social forces and 'moral' properties that permit different subject positions are, as we can see, related to political issues and power relations. This can be compared with the strong political writing of Davies and Harré (1999) about how our experiences and lived histories affect our subject positioning:

'Positioning' and 'subject position' [...] permit us to think of ourselves as choosing subjects, locating ourselves in conversations according to those narrative forms with which we are familiar and bringing to those narratives our own subjective lived histories through which we have learnt metaphors, characters and plot. (p. 41)

In this study, we focus on individuals' positioning through actions (van Langenhove and Harré 1999; Holland et.al. 1998), meaning that we understand positioning as verbs (Wagner and Herbel-Eisenmann 2009), as something one does to choose subject and to identify oneself in relation to how power relations determine the actual discourse. There are at least two ways to identify positionings from this dynamic view-interactional and reflexive. First, the verb 'position' can be understood as individuals' assumed intensions by positioning others, as for instance 'you're going to', 'you must' and 'I want you to’ (Herbel-Eisenmann et al. 2010; Walls 2005). Hence, when one positions another in an interaction, the positioning is interactive. The other way, which this article focuses, is reflexive and identifies how individuals position themselves within available discourses (cf. Davies and Harré 1999). This understanding of positioning enables an analysis of how the student positions herself through oral communication and physical movements in the educational contexts. We, like Herbel-Eisenmann, Wagner and Cortes (2010), see personal pronouns like "I" and "you" as strong markers for personal positioning. And, whereas positioning sometimes comes to include more people than the speaking subject, intergroup positioning identifies who are included and who are excluded in the actual positioning. Following Tan and Moghaddam (1999) intergroup positioning is "fundamentally achieved through the use of linguistic devices such as 'we', 'they', 'us', 'them', 'I' [and] 'you' (as a member of a certain group)” (p. 183).

\section{Power}

It is within the discourses power is working (Foucault 1971/1993), and hence, it is within discourses that power can be analysed (Wreder 2007). There are different layers where power relations occur in a discourse, and according to Foucault (1971/1993), communication occurs within restricted systems, or rituals. Rituals which determine who should take each position and what each individual may say and do. The discourse presupposes how to interpret different sayings and limits what can be said. If we want to understand how discourse and power are interrelated, we need to explore its occurrence in sequence, its regularities and limitations. In our study, our understanding of the flow of power within discourses is outlined by Foucault (1971/ 1993). 
In mathematics education research, issues of power are brought forward as a central aspect when analysing discourse (e.g. Andersson 2011b; Herbel-Eisenmann et al. 2010). Understanding how discourse is used implies being aware of equity issues and asymmetries in the discourse (Morgan 2012). Morgan stresses the importance of taking into account smaller (micro) studies to understand power relations within broader (macro) structures. We need to "look outside the immediate practice of individual classrooms to consider the dominant discourses and social structures that shape the resources that students and teachers bring with them into the classroom" (Morgan 2012, p. 182-183). By taking a micro perspective, this study hence contributes to understanding how power relations may affect discourses within mathematics teacher education from a broader perspective.

Valero (2004) outlines three ways of interpreting power and its consequences for research in mathematics education. First, she strongly rejects the assumption that power is within the mathematics subject, that mathematics is a powerful knowledge, and that mathematics education empowers people. "Saying that mathematics is powerful means that mathematics itself can exert power [and hence that] mathematics is given a life of its own that it does not have" (p. 13). Second, power can be seen as a capacity of people, or groups of people, to maintain social structures of inclusion and exclusion. This conception of power, rooted in the Marxist and Critical traditions, have been challenged in ethnomathematics and equity research and highlights the "necessity of questioning both mathematics and mathematics education practices" and "of incorporating critique as an essential element of a socio-political approach" (p. 15).

The third way of defining power - and the one for which Valero (2004) argues - is related to postmodern and poststructuralist understandings and seen as "situational, relational and in constant transformation" (p. 15) and draws from the Foucauldian understanding of power. This means that we cannot see power as stable or intrinsic to, i.e. social class or gender. Neither that power is built into the mathematics itself nor that receiving power relates to being mathematics educated. Referring to Popkevitz (2002), Valero expresses this different way of defining power "as a relational capacity of social actors to position themselves in different situations and through the use of various resources of power" (p. 15). Power could thus be used as an analytic tool in different contexts without limitations regarding race, gender, degree of education, etc. This way of defining power resonates with the aim of this study. There are no highly conflictive situations and extreme inequalities in focus. Instead, we foreground mundane and compulsory activities within the mathematics teacher programme to analyse how power relations reveal becoming mathematics teachers' empowered or disempowered subject positioning and how these positionings hence affect the students' identity construction.

\section{Identity}

There is an agreement that identity is a key term in contemporary social analyses and that identity is understood as multifacetted and dynamic in its character (Brown and McNamara 2011). However, the range of interpretations regarding how identity can be understood varies ontologically; for Wenger (1998), our identities are formed through participation in communities of practice, whereas Gee (2000) suggests that peoples' multiple identities imply "being recognized as a 'kind of person', in a given context" connected to their performances in society (p. 99). From a sociopolitical stance, identity 
is something you do and not something you are (Gutiérrez 2013). We are inevitably drawn into power relations in different contexts (cf. Andersson 2011b), meaning that our identities are "(re)constructed in spaces and moments" (Gutiérrez 2013, p. 3). Hence, we follow Walshaw (2004) and suggest that identity might be "consented to through constant social negotiation" (p. 65). Brown and McNamara (2011) suggest identifications as ways of making sense of what individuals' experience: "[T]here are no identities as such. There are just identifications with particular ways of making sense of the world that shape that person's sense of his self and his actions" (p. 27).

Stentoft and Valero (2010) argue that a poststructural perspective allows them to "think of identity in terms of fragile identification processes embedded in discourse and, therefore, tightly related to peoples' actions and participation in on-going discursive practices" (p. 62). "Subjectivity" is often used instead of "identity" to grasp these on-going and changing relations "between the individual and that to which she identifies" (Walshaw 2004, p. 67). Walshaw describes identities as "fractured and fragmented [...], complex and multiple" (p. 80), whereas Palmer (2010, p. 51) writes that "the subject arises in a two-way movement; as an effect of power enacted by the subject, and as an effect of the power the subject is exposed to" (our translation).

We do not replace identity by subjectivity in this study. We use identity as a dynamic and multifacetted concept, as something an individual expresses to make sense of herself and her actions; and which can change and develop in relation to how subject positionings occur in the discourses. Subject, on the other hand, is used as positionings occur, since it is assumed that the individual chooses her subject positioning in the prevailing discourse.

We sum up this section by clarifying that our understanding of positioning, power and identity is that these concepts are dynamic, interrelated, embedded in contexts and developing in available discourses. These unstable relations are not only theoretical constructions. We argue that they are powerful methodological and analytical tools within the sociopolitical theoretical framework, which will be shown in the analysis. The dynamic among the concepts becomes visible when positionings change due to how power at play determines the discourses, and hence impact becoming mathematics teachers' identities.

\section{Methodology}

A sociopolitical approach in research comprises not only relevant theories and methodologies but also visibility of the researcher and consciousness of how consistency between these is maintained. Following Andersson (2011b), this study is sociopolitical with a "little p", by being aware of political issues, power relations and having a fair relation with the participants: "A researcher acknowledging a 'little p' emphasizes an awareness of political issues, is sensitive to power and relationships, and cares for research participants through a researcher 'attitude" (p. 30). The sociopolitical "P", that research power as such, is not the focus in this study. The "little p" approach supports the way data was collected. By taking a sociopolitical stance in the study, we strive to give student teachers a voice. A voice, which could be both a reference to singular stories and occasions, as well as to more common concerns, shared by more than single becoming teachers. Through this approach we found that subject positionings revealed 
discursive power relations (Skog and Andersson 2013a) and showed that some concerns were specifically expressed by immigrants (Skog and Andersson 2013b).

Methods

Ethnographic data, such as interviews, course documents and a rich research journal, was produced over a 2-year period in contexts typical to the teacher education programme. Through Kicki's participation in daily routines and developing on-going relationships with the students, we learnt about the social setting, its discourses and contexts. This approach made us sensitive to individual reactions and unforeseen incidents but also conscious of careful writing "that leads to empathetic understanding of the social world of others" (Emerson et al. 1995, p. 72).

Semi structured interviews built around themes like initial teacher education or experiences as mathematics learner were open to allow spaces for conversations about what participants found important. We were aware of how the interview context could affect which stories were told and how storylines emerged. Van Langenhove and Harré (1999) emphasize that, within conversations, it is important to grasp the dynamic character of positioning. The conversants are jointly creating both the storyline and the illocutionary force of speech acts. This implies that a speaker, who takes up a position by opening a conversation, can change position during the communication. Kicki as interviewer played an important role by posing questions, but that did not necessarily mean that the further conversation structure was determined. As seen in the first transcript below, the interviewee could choose whether or not to adopt the position that the interviewer initiated. This approach is in line both with the aim of the study because what the student choose to talk about is central and with the sociopolitical theoretical tradition because these choices may highlight issues of power at play in the interactions (Gutiérrez 2013).

Data from different sources is foregrounded in this article, produced to show how the students enacted both empowered and disempowered positionings related to courses in their educational programme. First, we present one particular interview with Theresa, conducted in the beginning of a mathematics course. Second, we present fieldnotes from the mathematics course where Theresa was an active participant. In the third data excerpt, we follow Anna through a sequence of three interviews. The last set of data derives from an interview with Jessica.

Theresa and Anna moved to Sweden as adults. Theresa had no work experiences from either country and sometimes struggled with how to handle cultural differences between her two home countries. As will be shown, she expressed disempowerment regarding institutional constraints, language and mathematics while attending the course. Anna had some teaching experiences from her country of birth, which was reflected through the interviews as she expressed concerns about mathematics, language, culture and institutional constraints related to courses in mathematics education. This education complements her prior education with a Swedish exam including mathematics as main subject. Jessica did not express language concerns in the same way as Theresa and Anna, since Swedish is her mother tongue. However, she was concerned about institutional constraints and how to deal with the mathematics content. The data transcripts are thus generated from four different contexts: an interview with Theresa and Kicki involved, a mathematics lecture; a longitudinal swoop from Anna's 
two first years; and at last an interview with Jessica and Kicki involved. All participants are given pseudonyms and since neither Theresa nor Anna spoke Swedish fluently, we adjusted the transcripts a little by complementing with small words to better make sense of the context.

The data processing was done in three steps. First, a summary of the situations was written to grasp central concerns. In this way, storylines emerged. Second, we identified personal and/or intergroup positionings in relation to each storyline and how relations of power affected the positionings. At this stage, it was necessary to ask "why an utterance was performed and not another" (Foucault 1969/2002, p. 30). As a third step, a reflective note was added to each situation. This note, inspired by Andersson (2011b), was written from the basis of the ethnographic work and in a fruitful way allowed the talk to be connected to the specific contexts in which they were told.

The analysis that follows illustrates how subject positioning and power relations were simultaneously working in the available discourses. From this analysis, we make suggestions about how students' identities with regard to the mathematics subject and as becoming teachers might be understood.

\section{Analysis}

\section{Theresa}

Theresa has attended the mathematics course for some weeks. She is not always present, due to her family situation. When she comes she is an active participant, though, and gives an interested impression (Kicki's research journal).

Kicki: How... this course you take... How do you feel about it?

Theresa: Well... quite good. I don't know... yes.

Kicki: You are often involved and respond to questions and... when it comes to mathematics and stuff. Are you confident?

Theresa: Yes, yes, yes! In KOMVUX [municipal adult education] I have had many... what can I say, eh... good grades all the time. I have not... But, what I have learnt here is a lot more about language. That is my problem. And... It is about life experience too... what one needs. Since I haven't had any child in the Swedish... eh, school, I have no experience of that. And I haven't been working either. Everything affects me from the beginning and I have had a bad mentor who pressed me very much. But maths...

Kicki asked Theresa to tell more about the specific course and invited her to do this by saying that she recognized that Theresa was active during the lectures and sometimes posed questions to the teacher. Theresa positioned herself in different ways with regard to this: first, in relation to the mathematics she has learnt in Sweden; second, in relation to her language difficulties and lack of cultural experiences; and third, in relation to her supervising teacher, whom she disliked. Three discourses were thus 
working simultaneously and through Theresa's enacted positionings within each of them, it is possible to reveal how power relations affected the discourse. She did not take up the position of herself being an active student. However, within the mathematics discourse, Theresa expressed empowered positioning, since she always got good grades. On the other hand, she expressed disempowerment with regard to language and to be knowledgeable about the Swedish school system. Hence, she had experienced lots of demands which she expressed as difficult to handle. From these positionings, she identified herself as being positive towards and knowledgeable about mathematics, but at the same time as having language concerns and being novice in the Swedish culture.

Theresa interrupted Kicki's attempt to pose the next question and continued to talk about mathematics and about her difficulties in understanding the content of the mathematics compendium (containing university level texts and tasks):

Theresa: I've been taught by two teachers and I do not understand anything, still, of what is written in the compendium. So [the teacher] said to me, what [the teacher] explains is what is important; not what is written in the compendium.

Kicki: And you think you can follow along as [the teacher] explains?

Theresa: Yes, I understand what [the teacher] says, but I don't understand why and how to use it later. I don't know. But...

Kicki: [Poses a leading question.] Could you ask questions about that, when... because you sometimes do? Like 'how... isn't it supposed to be like this?' or...

Theresa: Yes, but I am a little unsure of the language, and because of that I... I have many, many questions [giggles]. And since [the teacher] is a bit... I don't know... is a bit unsure. Or... this is the first time [the teacher] teaches this course. I don't know how to pose questions. Because... when it comes to mathematics I can manage independently. I do not need the teacher so much. I'll be fine if I study a lot myself. (Interview, autumn 2011)

In this discussion, Theresa positioned herself in relation to mathematics, in relation to written and oral language and in relation to institutional frames. Kicki posed a leading question regarding Theresa's activity in class, and this time she took up the position of herself being an active student in the mathematics class. However, Theresa's positioning expressed disempowerment with regard to institutional constraints, such as written mathematical text in the compendium and how to pose questions to her teacher. The institutional discourse prevented her from being as active as she wanted as she did not challenge the power relations within the institutional discourse by posing questions, which possibly could have been misunderstood due to language confusion. Still, she expressed empowerment regarding her mathematical knowledge and said that she will be able to pass the course without the teacher's help. Theresa identified herself as knowledgeable in mathematics and independent of teacher support. At the same time she identified herself as having language difficulties and therefore dependent on teacher's explanations. 
From Theresa's discursive subject positionings, it is clear that discourses flow into each other and that positionings change and develops all time. The mathematics discourse appears as tightly connected with an institutional and constraining discourse at several instances during the actual course. What follows below is a short extract from one of the first lectures in the mathematics course (Field notes, 2011) where this phenomenon is prevalent.

The teacher talks about primes and prime factorization and asks: 'What is a prime?'

Classmate: A number one can divide by one and [the number] itself.

The teacher asks if the class can give an example.

Class: (in chorus) One.

Teacher: No, that is more like a convention. [She writes 2,3,5,7,11,13,17,19,23, ... on the chalk board]. Another number that can be written as a product of as small numbers as possible [writes $324=2 * 162=2 * 3 * 9 * 9=2 * 3 * 3 * 3 * 3 * 3$ ] Prime factorization is unique! There is exactly one way to prime factorize each number.

Theresa, who usually sits silently, raises her hand and asks:

Theresa: May I ask you a question? I understand the first line [2*162], but where does the three come from $[2 * 3 * 9 * 9]$ ?

The teacher re-writes $2 * 3 * 54=2 * 3 * 27=2 * 3 * 2 * 9 * 3=2 * 3 * 2 * 3 * 3 * 3$

Theresa does not get any response to her question. The teacher just corrects the mistake and returns to the agenda without considering whether the expression was correct - which it was not $[2 * 3 * 54 \neq 2 * 3 * 27]$.

In this extract, Theresa positioned herself in relation to the mathematics content by raising her hand and asking for clarifications. She expressed empowerment through her mathematical strengths but did not question the new writing. No one in the class commented either, which indicates that there might have been power relations present that prevented questioning of the correctness of the teacher's writings. Theresa identified herself as knowing the mathematical content and willing to share her knowledge with others by asking for clarification. However, she did not question the teacher. We conclude that Theresa expressed a strong mathematical identity despite the disempowering impact from the institutional discourse.

Anna

Anna has a deep interest in mathematics with reference to her own schooling, and she has a positive attitude to mathematics teaching. In the first interview, 2 weeks after the 
course started, she articulated that her expectation, to become a mathematics teacher, now was about to be realized. She was satisfied and happy over her educational choice.

Anna: Feels good... I am about to realize the expectations I had before I was accepted for the mathematics teacher education. And... I am happy that I chose mathematics as my orientation. So... it feels good (giggles)! /.../

I want to be the teacher who can support the students who need support. Not only support during lessons or related to teaching. Maybe they need other support. I just want to be the teacher who has her students as her family. So they feel safe when I am there teaching them. They can ask whatever they want to and I will answer... in a way they can understand. Making things easier and not so difficult for them, well, yes... I want to be a good teacher! Yes... (Interview 1, spring 2009)

Anna's positioning in the (mathematics) teaching discourse expressed empowerment, and she identified herself as a caring teacher who can support the children both with regard to mathematics and to their individual needs.

The second interview was conducted after the first teaching practice period, 11 weeks into the same semester. Anna was at that point in time concerned about the strong focus on language within the mathematics education courses. She thought:

Anna: What I ... I think there is much more that I have to concentrate on than language... When I started this course I thought completely different about mathematics. Not this math. I thought we would work a lot with numbers. But it was not ... There was a lot more with words, we should ... work. So I... I think ... yes...

Kicki: Can you tell me more? ... What do you mean by numbers... and what... what are the differences?

Anna: Well, I thought I wanted to study mathematics because I will work as a mathematics teacher. I will study addition and subtraction ... That's, much more advanced maths and yes ... This kind of thing in school that they use; fractions, decimal numbers and such, I thought. I have not thought that maths, that we will sit down and write an essay or... an assessment work or something. Much more I thought that we will be working with numbers and problem solving and such stuff. (Interview 2, spring 2009)

Anna's positioning revealed disempowerment both within the mathematics education discourse and in the language discourse. Nothing was what she had expected. The strong language focus in the mathematics education discourse revealed not only new ways of talking about mathematics teaching; a language discourse emerged wherein it was necessary to be skilled in the Swedish language. The new demands made her stressed and Anna related the language concerns to her immigrant background. This situation thus revealed power relations through her disempowered positioning. 
However, in the following piece from the same interview, Anna's positioning within the mathematics education discourse changed. The language discourse still disempowered her positioning and by using "we" she included other students in this discourse through intergroup positioning (cf. Tan and Moghaddam 1999). She talked about mathematics as more than numbers and that her view on mathematics now was different from what she earlier thought. Through this new empowered positioning Anna expressed an identity as becoming a good mathematics teacher.

Anna: Eh ... but when I started with this, it feels ... I get a lot of stress really. Very, very stressful. There is much to write all time and since we have a different background and we have not written or study so much here in the schools [in Sweden] and such, so it made a lot of the language skills if you say too ... I do not know /.../ I will move on. Yes, I intend to continue even if it was not what I expected from the beginning. Like, I thought about math, but it was not what I have figured in my head, but. I wanted to continue. I'm a bit like this stubborn man. I have never tired ... before. And I was teaching socio... civics, science ... like Swedish, but in my language, Arabic and such. But ... when I came to Sweden I thought maths, I haven't studied maths and that's something new, so I wanted to develop this and I want to work on it. Now everything is math. When you go shopping, when you go... your computer. Everything, it's just math that applies. So I thought "I must". And ... yes ... I think I will continue with this ... yes ... I will be a good teacher [giggles]... math teacher! (Interview 2, spring 2009)

Two years into the educational programme, Anna told me about a mathematics exam. She had failed two times and needed to pass next time to be allowed to continue her studies.

Anna: Last time. I had the written exam the day after my ... husband's father died. There were many... He is the oldest here and everybody came to our house. Well, one cannot say "actually, I have to prepare for my exam, you can go home". One cannot say so. So I knew nothing. I managed to do all parts, except the statistics. And [the teacher] wondered about that, because [the teacher] knew that I knew this... median, mean value, type value. And I didn't see the question. It was a basic level task. If I had seen that task I would actually have passed the first time. It was a pity. It's not that difficult. But the second time, statistics was good, but now I failed on a fraction task which I misunderstood...

Kicki: Do you think fractions are difficult in general?

Anna: No, some... some tasks are a bit difficult to understand, actually. What is it the teacher wants to know? So, that's the problem. I don't know. Maybe it is just a problem for us as immigrants.

Kicki: Do you mean how the questions are worded?

Anna: Well, it was obvious, actually. It was obvious. That's at least what I think. Yes, after I realized that [the teacher] had equal sharing in her mind. But I thought 
we should analyse the student's solution. That is what I did. Afterwards, when I came home, I read the question many many times and realized it wasn't was she wanted us to do. (Interview 3, autumn 2011)

Anna's positionings expressed disempowerment within several discourses simultaneously. Her family situation hindered her from studying as much as needed before the exam. As a consequence, she failed to solve an easy task and in the second exam there were some difficulties for her to understand what the teacher asked for, due to language confusions. With regard to this, she failed again and now needed to write the exam for the third time. So we could here see how four discourses - cultural, mathematics, language and institutional discourses - were working simultaneously. All of them affected Anna to express disempowered positionings, which was visible through utterances like, "one cannot say 'actually, I have to prepare for my exam, you can go home", "the second time, statistics was good, but now I failed on a fraction task which I misunderstood...", "some tasks are a bit difficult to understand, actually. What is it the teacher wants to know? /.../ Maybe it is just a problem for us as immigrants". We conclude that these expressions revealed power-relations in the discourses leading to that she did not express an identity as becoming mathematics teacher in this instance. Instead, she identified herself as university student and her only expressed wish was to pass the exam.

Jessica

In the following transcript from an interview with Jessica, the institutional discourse emerged as even more constraining and affected Jessica's subject positionings both within the institutional and the mathematics discourse.

Jessica: The way we sit here in the lesson isn't fun at all. Probably because I don't understand and don't see how to use this [mathematics].

The students sat in their benches watching the teacher who wrote on the chalk board (Kicki, field notes, 2011).

Kicki: What do you think about that? Is it just a frustration or...

Jessica: I feel a bit stressed. It's fun. I like to calculate if I have time, but now there are three weeks and then exam. And then you have family and children at home. I don't have time to study at home, neither in the evenings nor during weekends. Then I feel a bit stressed, it's hard. It's not fun. I do this only because I must proceed. One learns by doing it. I have done it before, but this feels just a bit harder compared to what I have done earlier. It's like a staircase. Now I just need to grab the bull by the horn and start. It will be finished sometime. I might do it again if needed. I cannot get so stressed for not missing the exam. In worst case I must do it again. I cannot let my family stand back too much. They must be first priority /.../

Jessica could not see the connection between the mathematics they were taught and how she might use it as a mathematics teacher. The institutional discourse affected 
Jessica's positioning to express disempowerment. She became pragmatic and talked about what she could do within the time limit due to family commitments. If she would fail, she said she can do the exam again later. Jessica's identity as becoming mathematics teacher was weak in comparison with her identity as a university student although the strongest expressed identity is as a mother and family member.

The institutional discourse constrained the mathematics discourse. Time limitations and course exams hindered the fruitful discussions about the mathematics content and Jessica's disempowered positioning indicated that there was not much she could do about it.

Jessica: Like in this course: we don't have time for discussions. If [the teacher] will have time for going through her theory, we will not have time for discussions, and then half the lesson is dedicated to that, and then half the point with this course [which aimed at developing a deeper understanding of the mathematics] gets lost. Hitherto I haven't seen much of that.

The questions we ask are posed because [the teacher] writes so fast. I and many others don't have time to see all the lines [the teacher] writes. And then [the teacher] elaborates some lines, all... and some of them [the teacher] merge and then it goes too fast. When [the teacher] begins with a new calculation we haven't had time to think through [the teachers] lines. It is those questions we ask. There are more questions regarding how to calculate, not interesting questions, really,,, and discussions about the concepts. I think the questions are narrower: "What does it say there? What have you written there? How did you get there?", and the like. The questions I have asked: "Can we discuss this? Can we relate this to everyday...?" "Yes I will think about that..." and then nothing more happens. So the discussions in class are mainly questions about how to calculate. So, I think I'll quit. It's only three weeks left. It doesn't work. I must continue calculating. That's the way... (Interview, autumn 2011)

Jessica expressed empowerment with regard to mathematics, but the institutional constraints affected the mathematics discourse. Timewise, everything was supposed to progress in a high speed. This made the qualitative discussions she expected in this course absent. Through Jessica's discursive subject positionings, we may understand how she made sense of what she experienced and how she identified herself as becoming mathematics teacher. First and foremost, she asked for connections between the university education and her future profession; a connection she did not recognize. The particular course should offer deep discussions about mathematics. However, what she experienced was too high speed and superficial questions from them as students, which aimed at passing the exam without deeper reflections on the relationships between the university courses and her future identity as a mathematics teacher. We conclude that the two identities Jessica expressed, as university student and as becoming teacher, are separated. Jessica merely expressed a wish to finish the course so she could get her exam and start working.

\section{Discussion}

In this article, we explored how a sociopolitical analysis could contribute to our understanding of critical aspects and concerns raised by mathematics student teachers 
during their time at university. We posed the question how power relations in university settings may affect becoming mathematics teachers' subject positioning and hence affect the students' identities. We showed possibilities using theories of positioning, power and identity in a complementary way to analyse and understand the complex processes where power relations affect available discourses, reflected through students' expressions of empowered and disempowered positionings.

We showed how Theresa, Anna and Jessica at times struggled to make sense of themselves as becoming mathematics teachers because simultaneously working discourses did not interact, and thus the mathematics education discourse was not foregrounded. Prevailing was instead the dominant institutional discourse within which all three students enacted strong disempowered positionings. Institutional constraints seemed not possible for the students to challenge, whether it was about course content, student-teacher relations or written exams. As we drew attention to earlier, the mathematics discourse was challenged since the connection between the mathematics they were taught and their future profession as mathematics teachers was invisible. The mathematical discourse had a strong focus on solutions and high-speed calculations, which according to the students in this study prevented deeper understanding of the content. In order to pass the exam, they all accepted the discourse of superficial learning. The immigrant students accepted the language discourse in a similar way. The students did not even challenge the language discourse since there seemed to be no options for them to affect or change this prevalent discourse.

By exploring these relations from a sociopolitical perspective we recognized that both the institutional and the language discourse intersected with the mathematical discourse, whereas the mathematics education discourse largely remained marginalized. Consequently, the students' identities were adjusted to fit the dominant discourses, which not necessarily resulted in enacted identities as becoming mathematics teachers. Drawing on Foucault's notion of discursive power relations (1971/1993), the analysis also foregrounded that students who talked about language constraints, were they who had another mother tongue than Swedish. These students were hence allowed to take this position and express disempowerment within the language discourse. They also had the power to analyse mathematics education critically by taking a stance within their previous experiences in their country of birth. This way of analysing power relations allowed us to say something about who may say what, and to ask why some utterances were expressed and not others (Foucault 1969/2002). Positioning became a useful analytical tool through which we could identify discursive power relations. The sociopolitical analysis of how students made sense of themselves and their actions hence facilitated our understanding. About critical aspects that affected becoming mathematics teachers' identity construction.

\section{Conclusions}

We have shown that power relations and subject positioning in social settings are critical aspects and need to be taken seriously into account if we aim at understanding becoming teachers' identities. Previous research in Sweden has shown that novice teachers are constrained by the degree of subject-oriented responsibility and work situation in schools (Palmér 2013) and by concerns about their competence as 
mathematics teachers (Persson 2009). By taking a sociopolitical perspective, we have shown that institutional constraints may obscure possibilities do deepen and develop identities as mathematics teachers. We need, within the educational programmes, to be more aware of which discourses that are made available for becoming teachers and strive for opening up discourses to be challenged and resisted.

We argue that the sociopolitical theoretical perspective allows the analysis to reveal underlying factors that affect students' talk about their situation. The approach we take in this article facilitates a move behind description and reveals how power fluctuates in the discourses, an approach that provides a complementary way of understanding becoming teachers' situations and concerns during teacher education - an understanding that can provide new dimensions on learning to teach mathematics.

\section{References}

Adler, J., \& Davis, Z. (2006). Opening another black box: researching mathematics for teaching in mathematics teacher education. Journal for Research in Mathematics Education, 37(4), 270-296.

Andersson, A. (2011a). A "Curling teacher" in mathematics education: teacher identities and pedagogy development. Mathematics Education Research Journal, 23(4), 437-454.

Andersson, A. (2011b). Engagement in education: Identity narratives and agency in the contexts of mathematics education (Doctoral dissertation). Aalborg: Aalborg University

Atweh, B. (2009). What is this thing called social justice and what does it have to do with us in the context of globalisation? In P. Ernest, B. Greer, \& B. Sriraman (Eds.), Critical issues in mathematics education (pp. 111-124). USA: Information Age Publishing Inc.

Bjerneby Häll, M. (2006). Allt har förändrats och allt är sig likt: En longitudinell studie av argument för grundskolans matematikundervisning [Everything has changed and all remains the same] (Doctoral dissertation). Linköping: Linköping University

Brown, T., \& McNamara, O. (2011). Becoming a mathematics teacher: identity and identifications. Dordrecht: Springer.

Davies, B., \& Harré, R. (1999). Positioning and personhood. In R. Harré \& L. van Langenhove (Eds.), Positioning theory (pp. 32-52). Oxford: Blackwell.

de Freitas, E., \& Zolkower, B. (2009). Using social semiotics to prepare mathematics teachers to teach for social justice. Journal of Mathematics Teacher Education., 12, 187-203.

Emerson, R. M., Fretz, R. I., \& Shaw, L. L. (1995). Writing ethnographic fieldnotes. Chicago: The University of Chicago Press.

Foucault, M. (1969/2002). The archaeology of knowledge. (A. M. Sheridan Smith, Trans.) London, New York: Routledge.

Foucault. (1971/1993). Diskursens ordning [The order of discourse] (M. Rosengren, Ed \& Trans). Stockholm: Symposium.

Gee, J. P. (2000). Identity as an analytic lens for research in education. Review of Research in Education, 25, 99-125.

Gutiérrez, R. (2013). The sociopolitical turn in mathematics education. Journal for Research in Mathematics Education, 44(1), 37-68.

Hansson, Ö. (2006). Studying the views of preservice teachers on the concept of function (Doctoral dissertation). Luleå: Luleå University of Technology.

Herbel-Eisenmann, B., Wagner, D., \& Cortes, V. (2010). Lexical bundle analysis in mathematics classroom discourse: the significance of stance. Educational Studies in Mathematics, 75(1), 23-42.

Holland, D., Lachiotte Jr, W., Skinner, D., \& Cain, C. (1998). Identity and agency in cultural worlds. London: Harward University Press

Lerman, S. (2000). The social turn in mathematics education research. In J. Boaler (Ed.), Multiple perspectives on mathematics teaching and learning (pp. 19-44). Westport: Ablex.

Morgan, C., Holland, Lachiotte Jr, Skinner, \& Cain (2012). Studying discourse implies studying equity. In B. Herbel-Eisenmann et al. (Eds.), Equity in discourse for mathematics education (pp. 181-192). Netherlands: Springer. 
Nilsson, G. (2005). Att äga pi [To own pi]. (Doctoral dissertation). Göteborg: Göteborgs universitet.

Palmer, A. (2010). Att bli matematisk: Matematisk subjektivitet och genus i lärarutbildningen för de yngre åldrarna (Doctoral dissertation). Stockholm: Stockholm University.

Palmér, H. (2013). To become, or not to become, a primary school mathematics teacher: A study of novice teachers' professional identity development. (Doctoral dissertation). Växjö: Linnaeus University Press.

Persson, E. (2009). Det kommer med tiden: från lärarstudent till matematiklärare. (Doctoral dissertation). Stockholm: Institutionen för didaktik och pedagogiskt arbete.

Popkewitz, T. (2002). Whose heaven and whose redemption? The alchemy of the mathematics curriculum to save (please check one or all of the following: (a) the economy, (b) democracy, (c) the nation, (d) human rights, (d) the welfare state, (e) the individual). In P. Valero \& O. Skovsmose (Eds.), Proceedings of the Third International Mathematics Education and Society Conference (2nd ed., pp. 35-56). Copenhagen: Centre for Research in Learning Mathematics.

Potter, J., \& Wetherell, M. (1987). Discourse and social psychology. Beyond attitudes and behaviour. London: Sage.

Sánchez, M. (2011). A review of research trends in mathematics teacher education. PNA, 5(4), 129-145.

Setati, M. (2008). Access to mathematics versus access to the language of power: the struggle in multilingual mathematics classrooms. South African Journal of Education, 28(1), 103-116.

Skog, K., \& Andersson, A. (2013a). Exploring identity positioning as an analytical tool. In M. Berger, K. Brodie, V. Frith, \& K. le Raux (Eds.), Proceedings of the seventh international mathematics education and society conference, Cape Town 2nd-7th April 2013 (pp. 441-451). Cape Town: Hansa Print Ltd.

Skog, K., \& Andersson, A. (2013b). Immigrant mathematics teacher students' subject positioning. Proceedings of the 37th Conference of the International Group for the Psychology of Mathematics Education (4th ed., pp. 233-240). Kiel: PME.

Sriraman, B., \& English, L. (2010). Surveying theories and philosophies of mathematics education. In B. Sriraman \& L. English (Eds.), Theories of mathematics education. Berlin Heidelberg: Springer.

Stentoft, D., \& Valero, P. (2010). Fragile learning in the mathematics classroom. In M. Walshaw (Ed.), Unpacking pedagogy-new perspectives for mathematics classrooms (pp. 87-107). Charlotte: Information Age Publishing Inc.

Tan, S. L., \& Moghaddam, F. M. (1999). Positioning in intergroup relations. In R. Harré \& L. van Langenhove (Eds.), Positioning theory (pp. 178-194). Oxford: Blackwell.

Valero, P. (2004). Socio-political perspectives on mathematics education. In P. Valero \& R. Zevenbergen (Eds.), Researching the socio-political dimensions of mathematics education: issues of power in theory and methodology (pp. 5-23). Boston: Kluwer Academic Publishers.

Valero, P. (2009). What has power got to do with mathematics education. In P. Ernest, B. Greer, \& B. Sriraman (Eds.), Critical issues in mathematics education (pp. 237-254). USA: Information Age Publishing Inc.

van Langenhove, L., \& Harré, R. (1999). Introducing positioning theory. In R. Harré \& L. van Langenhove (Eds.), Positioning theory (pp. 14-31). Oxford: Blackwell.

Wagner, D., \& Herbel-Eisenmann, B. (2009). Re-mythologizing mathematics through attention. Educational Studies in Mathematics, 72(1), 1-15.

Walls, F. (2005). Using rights-based frameworks for rethinking teacher-directed pedagogies of mathematics. Proceedings of the 4th International Mathematics Education and Society Conference 4th International Mathematics Education and Society Conference, 2-6 July 2005 (pp. 296-306.). Gold Coast: MES.

Walshaw, M. (2004). Preservice mathematics teaching in the context of schools: an exploration into the constitution of identity. Journal of Mathematics Teacher Education, 7, 63-86.

Wenger, E. (1998). Communities of practice: learning, meaning and identity. Cambridge: Cambride University Press.

Wreder, M. (2007). Ovanliga analyser av vanliga material: Vad diskursteorin kan göra med enkäter. In M. Börjesson \& E. Palmblad (Eds.), Diskursanalys i praktiken (pp. 29-51). Stockholm: Liber. 